\title{
Os grupos juridicamente vulneráveis e a formação da legalidade e do judiciário brasileiro: histórico e tendências do acesso aos direitos e à justiça no Brasil
}

\section{Vulnerable groups and the formation of legality and of the brazilian judiciary: history and trends in the access to justice in Brazil}

\author{
Renata Ovenhausen Albernaz \\ Camila Salgueiro Purificação Marques**
}

\begin{abstract}
Resumo: Este trabalho tem por objetivo evidenciar, em termos históricos, algumas manifestações institucionais da organização da legalidade e do judiciário brasileiros que contribuíram para a formação e a reprodução de grupos juridicamente vulneráveis no País; estes, entendidos como sendo a parcela da população despida dos direitos que socorram suas principais necessidades ou do acesso à justiça que garanta efetividade aos poucos direitos legais por ela conquistados. Neste percurso, destaque também é dado às soluções estatais, bem como às construídas pela sociedade civil, a esta vulnerabilidade jurídica, verificadas nestas duas últimas décadas em virtude do processo de redemocratização no País. A pesquisa se desenvolveu a partir de uma abordagem indutiva, com base em dados históricos coletados em fontes bibliográficas e documentais.
\end{abstract}

Palavras-chave: Judiciário. Grupos juridicamente vulneráveis. Acesso à justiça.

\begin{abstract}
This paper illustrates from a historical perspective some of the institutional manifestations of the organization of legality as well as of the Brazilian Judiciary and their contribution to the formation and reproduction of legally vulnerable groups in the country. These groups are understood as the portion of the population that has no access to their main needs or access to justice so that the few rights they have conquered are attended. The paper also highlights the state solutions and those given by civil society to the judicial vulnerability observed in the last decades due to the redemocratization of the country. The study was developed from a historical and critical approach using documents and bibliographical sources.
\end{abstract}

Keywords: Judiciary. Legally vulnerable groups. Access to justice.

\footnotetext{
Doutora em Direito pela Universidade Federal de Santa Catarina (UFSC). Professora Adjunta na Universidade Federal de Pelotas (UFPEL), atuando nos cursos de Doutorado e Mestrado em Memória Social e Patrimônio Cultural (PPGMP), no Mestrado em Ciência Política (PPGCPOL) e na Graduação em Direito. Pelotas, Rio Grande do Sul, Brasil. E-mail: renata_albernaz@terra.com.br

" Mestranda em Direito pela Pontifícia Univerisdade Católica de São Paulo (PUC-SP). Advogada. Bacharel em Direito pela Universidade Estadual de Ponta Grossa (UEPG). São Paulo, São Paulo, Brasil. E-mail: camila_purificacao@yahoo.com.br
} 


\section{Introdução}

Muito já se discutiu, na sociologia jurídica nacional, acerca do enviesamento do direito brasileiro aos interesses das elites dominantes, seja no contexto atual seja em uma análise histórica das instituições jurídicas. ${ }^{1}$ Nessas discussões, fala-se, várias vezes, dos reflexos desses interesses na estrutura jurídica positiva e na sua justificação promovida pelas principais correntes teóricas e ideológicas que se instalaram no País por meio das escolas de direito e das instituições de pesquisa em geral; e como implicação desse cenário, é denunciada a geração da marginalidade de vários grupos sociais a este direito positivo e ao acesso às instituições estatais. Nesta percepção, esses estudos pugnam por um olhar crítico ao direito e ao Estado, capaz de desvelar esses enviesamentos, e a consequente marginalização, advogando um novo paradigma jurídico que promova maior inclusão e justiça social.

Este trabalho se insere nessas discussões, procurando evidenciar, em termos históricos, algumas manifestações institucionais da organização da legalidade e do judiciário brasileiros, que contribuíram para a formação e a reprodução do que chamamos "grupos juridicamente vulneráveis" no País; estes, entendidos como sendo a parcela da população despida dos direitos que socorram suas principais necessidades ou do acesso à justiça que garanta efetividade aos poucos direitos legais por ela conquistados. $\mathrm{O}$ estudo se desenvolveu a partir de uma abordagem indutiva, com a coleta de dados históricos, com base em fontes documentais e bibliográficas, sobre a formação e regulamentação da legalidade e do poder judiciário no Brasil. O teor crítico deste trabalho advém de que, a partir dessas coletas, buscou-se evidenciar, por meio das recorrências de abundâncias e de ausências de direitos e de acesso à justiça, as pessoas e os grupos sociais que foram historicamente constituídos como juridicamente vulneráveis no Brasil. A leitura das leis, de documentos judiciais e dos textos de estudiosos sobre a formação do Estado Brasileiro, assim, buscou destacar

\footnotetext{
1 Entre essas discussões, fazemos destaque, aqui, àquelas promovidas por autores brasileiros como Gomes (1958), Machado Neto (1979), Lyra Filho (1982), Faria (1988), Novoa Monreal (1988), Arruda Jr. (1993), Wolkmer (1998; 2002; 2003), Andrade (2003), entre outros.
}

as referências destes ao posicionamento que a legalidade e o judiciário do País davam a conflitos de interesse de grupos sociais, identificados segundo um recorte de classe e étnico-racial, tais como trabalhadores e patrões, proprietários e não proprietários, escravos e senhores, negros, índios e brancos, camponeses e latifundiários. A hipótese norteadora dessa pesquisa era de que vários desses posicionamentos legais e da organização judiciária, apesar de diversos e pontuais, comporiam, no Brasil, uma orientação político-jurídico-ideológica nessas instituições, que permitiria e reproduziria uma situação de vulnerabilidade jurídica a alguns grupos e pessoas, vulnerabilidade esta evidenciada seja em virtude das ausências e deficiências de direitos e de acesso à justiça a tais grupos e pessoas, seja pela abundância de direitos para os grupos de interesses contrários, seja, ainda, por um sentido de neutralidade legal e judiciária que desconsiderasse desigualdades sociais reais no País.

Um dos pressupostos desta pesquisa, tendo em conta esse sentido de vulnerabilidade jurídica que se buscava evidenciar, era a importância da correlação entre a existência (e a conquista) de direitos e o necessário acesso à justiça como meio de efetivá-los. Daí que este texto se estruturou buscando apresentar, primeiro, aspectos da orientação político-jurídico-ideológica mais geral da formação do Estado Brasileiro, com destaque àqueles que se refletiram na legalidade, na organização do poder judiciário e no acesso à justiça. Os aspectos pontuais, mas relevantes, veiculando interesses jurídicos de alguns grupos sociais (trabalhadores e patrões, proprietários e não proprietários, escravos e senhores, negros, índios e brancos, camponeses e latifundiários) foram apresentados para induzir nossas conclusões no sentido de caracterizar esta vulnerabilidade jurídica no País e o modo como se dava sua produção. Em um segundo momento, o estudo apresenta como os atuais processos de redemocratização, as lutas populares e a própria tematização pública do acesso à justiça têm colaborado para problematizar esta histórica produção de vulnerabilidade jurídica no País, e quais as soluções contemporâneas propostas para superá-la. 


\section{A formação da vulnerabilidade jurídica na consolidação dos princípios de direito e da legislação no Brasil}

A tão grande influência da colonização portuguesa no configurar de nosso Estado e Direito torna necessária, para entender a gênese destes, uma recuperação do modelo de colonização português e de alguns elementos da cultura ibérica que eivaram nossa formação social, à época. Uma das características deste modelo de Estado era a mescla, muitas vezes paradoxal, entre a busca pelo formalismo e o racionalismo legal e burocrático e o exercício concreto do personalismo social ibérico. No que tange ao direito, Rosenn (1998, p.17-22) afirma que este paradoxo foi influenciado por impulsos dos mais variados, decorrentes seja do ímpeto racionalizador e especializante da juridicidade verificado no movimento de recepção do Direito Romano, seja na persistência do pluralismo legal medieval ibérico, ou na forte presença do dogmatismo e do conservadorismo da Igreja Católica na direção do Estado e do Direito, em Portugal e na Espanha, à época colonial brasileira. Esta mescla, somando aspectos de racionalização e de dogmatismo extremos com uma cultura ainda personalista, restou, nos países colonizados, paralelamente às soluções legalistas, burocráticas e racionais, à criação de uma "cultura do jeito" como parte integrante da operacionalidade institucional e jurídica do Brasil, cultura que ficou tão presente a ponto de, muitas vezes, o jeito se tornar a regra, e a norma jurídica, a exceção, diz o autor (ROSENN, 1998, p.20). A força dessa "cultura do jeito", assim, imunizou a eficácia do ideal de igualdade formal, ditado desde os primórdios da formação da racionalidade jurídica moderna do Ocidente, e possibilitou a vigência institucional de fatores opostos a tal igualdade, tais como o nepotismo, a política de favores, o patrimonialismo e o clientelismo.

Além desta mescla paradoxal entre fatores racionais e pessoais na institucionalidade cultural do Estado e do Direito, o formato de Estado centralizador português também cooperava para imunizar os princípios modernos das liberdades privadas, da igualdade e da livre iniciativa, que já inflamavam a juridicidade europeia da época coIonial do Brasil, fatos que dificultaram a ascensão social dos não nobres ou dos não vinculados ao
Estado - ascensão esta que ocorreu em países cujos primórdios do capitalismo foram dirigidos mais pelo poder econômico privado do que pelo poder público, como foram os casos da Inglaterra e da França.

Faoro (2001), nesse sentido, destaca um importante aspecto que contribuiu para esta imunização dos ideais de igualdade e liberdade na colônia Brasil. Este autor (2001, p.24) afirma que, por não ter passado pelo feudalismo europeu, Portugal desenvolveu o denominado "capitalismo comercial" e, desde muito cedo (1147), estava ligado ao comércio marítimo e à navegação internacional, exportando produtos de base, como o sal, o pescado, o vinho, o azeite, as frutas, o couro, a cortiça. Este comércio, no entanto, não foi mobilizado por uma burguesia revolucionária, mas pelo próprio Estado Português, firmando seu cunho patrimonial e centralizador; dessa forma, o confronto com tal "monopólio comercial real" fragilizava, quando não corrompia, pela cooptação, a ação dos agentes que poderiam ter sido os propagadores das liberdades e das igualdades públicas, tornando muito mais fraco o movimento social em direção a ambas na península ibérica e em suas colônias do que em outros países, nos séculos XVI a XVIII. A "burguesia" acabava, assim, revela Faoro (2001, p.24-36), sendo de servidores do Estado, e foi constituída a partir da própria nobreza em declínio, pagando o rei por todos os abusos, roubos, contratos fraudados, que eram comuns nessa nobreza até então, mas que passaram a ser cometidos, também, na seara das funções estatais; ela era, ainda, uma aristocracia "habituada à inércia", avessa ao trabalho, pois que para os portugueses da época, continua o autor (2001, p.105-6), era mais louvável "ser uma aristocracia de pobres ociosos, a ser uma democracia próspera de trabalhadores". Tal aversão ao trabalho manual (na exploração agrícola, mineira ou industrial) teve como consequência não só a formação de uma aristocracia estatal viciada em regalias e no pouco compromisso público, como também certo atraso no desenvolvimento industrial, seja em Portugal ou em suas colônias. Toda a riqueza, por isso, vinha do comércio, mas o rei o comandava quase por inteiro, sendo que os lucros dessa atividade eram destinados aos confortos do rei e de tal aristocracia, ao arrepio das necessidades de todo o resto da população. 
O único segmento da nação que, à época, poderia ensejar o renascimento econômico por ter sido excluído dos poderes públicos e por ser rebelde à tutela estatal eram os judeus, mas estes foram esmagados por uma "fúria purificadora" quase sem igual na história, ${ }^{2}$ o que demonstra que, além de centralizador, o Estado Português e o colonial eram intolerantes e combatiam, ferozmente, as resistências civis. ${ }^{3}$

Além deste fator de imunização dos princípios modernos da igualdade e da liberdade, destacado por Faoro, outros, ainda, podem ser aventados. Entre eles está a pouca preocupação do colonizador português em constituir na Colônia uma nação, um dos requisitos políticos dos Estados modernos na Europa, e que contribuiria para uma visão de maior equilíbrio entre a população no Brasil. Neste fator, Faoro (2001, p.45) vislumbra que a finalidade de exploração de riquezas deste capitalismo comercial em relação às colônias as fez serem representadas como meras fontes de riqueza e de bens comercializáveis, de tal modo que o povoamento só se deu em virtude da necessidade de proteção contra as invasões estrangeiras e ao preço de o povoador aceitar vir ao Brasil apenas para angariar privilégios, terras e status concedidos pelo rei. O colonizador vinha desacompanhado da família porque tinha o intento de retornar a Portugal logo que conseguisse enriquecer, de modo que não se instalava com o intuito de firmar uma "nova nação" e pouco se importava com os desígnios da Colônia e de seus povos nativos. Foi uma colonização, assim, diferente

\footnotetext{
2 Segundo Faoro (2001, p.104) tal "fúria purificadora" se constituiu no fato de os judeus terem que abandonar o país, forçados por obscuros brios nacionalistas ou de monopólio do poder político. "A inquisitorial fúria purificadora expulsou, esmagou e acabou com o judeu, abrindo um vácuo que o inglês preencheria - o judeu, no caso, foi apenas um símbolo, menos que uma realidade, do burguês moderno, flexível e permeável aos novos tempos."

${ }^{3}$ Exemplo deste modo de agir violento do estado português para com as resistências sociais advém da própria formação do Estado Brasileiro. Segundo apontam Slemian \& Pimenta (2003), a formação do Estado brasileiro se deu por uma contingência - a vinda da família real para o país e a necessidade de compor aqui todo o aparato burocrático da Colônia - e foi promovido com atos de violência, diante da resistência de boa parte daqueles que aqui resistiam em criar um Estado separado da capital portuguesa. O Estado brasileiro, assim, fora instalado de modo coercitivo, para fins de atender interesses prioritariamente da metrópole, e ao alvedrio dos interesses da maioria dos grupos de poder locais.
}

da processada na América do Norte, pois, nesta última, o colonizador inglês, buscando liberdades e fugindo das perseguições, principalmente religiosas, na Inglaterra, "fundou na América uma pátria", ao passo que "o português formou um prolongamento do Estado" de Portugal na Colônia, explorando, no interesse deste, as riquezas e o povo do novo mundo o máximo possível.

Além disso, a desigualdade foi reforçada pelo modo agressivo da exploração colonial que, deliberadamente, optou pela concentração, e não pela distribuição das riquezas e oportunidades. Segundo observa Paulilo (1996, p.21), a combinação do binômio "terra vasta e pouco valorizada", por um lado, e rígido controle, pelas classes dominantes, sobre as fontes de riqueza de outro, era observada porque no Brasil colonial, a terra, sendo muita, acabava pouco valorizada se nela não houvesse gado ou se seu proprietário não dispusesse, primeiro, de escravos, depois, de mão de obra barata para fazê-la produzir sem esses dois usos, a terra não gerava valor e, assim, não tinha valor. $E$ a metrópole queria terras produtivas. Tanto foi assim que o rei instituiu, por meio da Carta Régia de 20 de janeiro de 1699, que as terras não cultivadas ou ocupadas passassem a ser consideradas devolutas, podendo ser repassadas pela Coroa, novamente, em sesmaria, àqueles que denunciassem a existência e a localização dessas terras incultas. Daí a importância da escravidão de índios e, depois, de negros africanos para manter a produção de riqueza pela terra, pois, assevera Martins (1986, p.110), "ser senhor de escravos era condição para ser senhor da terra e senhor das gentes", ou seja, quem não preenchesse esta condição (ter dinheiro para comprar e manter escravos e gado) não poderia ter a terra, seria um desapossado. O regime de exclusão ainda se afirmava sobre os povos nativos (índios), estes, desde o início, desconsiderados pelos colonizadores, pois as terras dos índios eram tidas como livres, podendo ser ocupadas por qualquer posseiro branco que alcançasse uma concessão régia.

Um quarto aspecto que cooperou para imunizar os ideais de igualdade e de dignidade humana se refere ao fato de que o supracitado paradoxo entre a busca de regulação estatal e a vigência de um poder pessoal desregulado 
também permite graves abusos e arbítrios, pois a Metrópole permitia, por sua omissão, um poder social quase sem limites ao colonizador nos assuntos restritos às terras do novo mundo. Souza (2006, p.126) contraria o pressuposto de Faoro acerca da influência portuguesa, decisiva na formação das instituições estatais e da consequente desigualdade brasileira; ele defende a tese da singularidade da formação social no Brasil em virtude da peculiar instituição da escravidão neste país em relação à ausência dessa experiência em Portugal e no resto da Europa da época, e afirma, no contraponto às teses do impulso centralizador da Metrópole, que o poder do colonizador interno era praticamente ilimitado. Souza (2006, p.132) enfatiza que na obra de Freyre se revela o componente sadomasoquista como um constitutivo deste poder, na medida em que as inclinações pessoais do patriarca decidiam, em última instância, o tamanho do núcleo familiar e a proporção de proteção a cada qual; não havia praticamente nenhuma limitação externa a este arbítrio do senhor de escravos, pois, no que se refere a estes, os preceitos de dignidade humana, já presentes no direito natural e na fé cristã, na Europa, tiveram pouca penetração e eficácia no Brasil. O componente de "proximidade" social entre desiguais, que Freyre enfatiza, ao lado do componente violento e segregador, revela o caráter instável, imprevisível e particularista das relações sociais no Brasil. A total dependência dos escravos em relação ao senhor, sem nenhum costume ou tradição a proteger seus direitos, como o era em outros povos, abalava sua autoestima e os fazia projetar e idealizar a vida do colonizador, inclusive com o mestiço pretendendo ser reconhecido como branco, e não como negro. A proteção era discricionária e, possibilitada pela influência árabe da família poligâmica, era aberta a todos aqueles que aderissem aos valores do pai e fossem, por conta disso, por ele reconhecidos. Esta relação, conclui Souza (2006, p.120-1), contaminou todos os demais tipos de relações de dependência, mesmo as que envolviam pessoas livres, formando uma "ralé social" que, sendo dispensável, vivia na dependência, nas franjas ou margens do sistema.
Tais aspectos de uma orientação ao mesmo tempo centralizadora estatal e descentralizadora pessoal contribuíram para criar um abismo entre a elite governante - estatal e colonizadora - e a massa da população - alijada do poder e entregue aos arbítrios do rei e desta elite. No que se refere aos direitos desta massa, Cesar (2002, p.116) amplia a perspectiva ao dizer que, neste contexto,

Além do negro e do índio, alijados da e pela legalidade colonial em razão da escravidão, outros setores da sociedade também tinham o mesmo destino: judeus, muçulmanos, europeus miseráveis perseguidos por dívidas, hereges, e todos aqueles excluídos da empresa colonial não compartilhavam de mínimos direitos e prerrogativas. Decorre daí uma distinção entre o Direito do Estado Colonial e o Direito do povo excluído da Colônia, [...].

As instâncias de poder também eram particularistas e elitistas, não se preocupando com os interesses nacionais e sequer se importando em buscar qualquer legitimidade social para seu poder, de tal modo que, assevera Wolkmer (2003, p.40), tais instâncias se consolidavam apenas com base na aliança do poder aristocrático da Coroa com as elites agrárias locais, formando um modelo agrário de Estado que defenderia sempre, mesmo depois da independência, os intentos de segmentos sociais donos das propriedades e dos meios de produção. Do mesmo modo, as legislações até o século XX não indiciavam qualquer anelo por consolidar um sentido de totalidade de interesse nacional e, assim, de maior equilíbrio nas relações sociais, o que se verificava pela vigência tardia (até 1916) das ordenações portuguesas a regular as relações civis no Brasil. Não se pode negar, porém, que as primeiras escolas de Direito tinham como metas a elaboração de um código único e desvinculado da tutela colonial e a formação de uma elite intelectual autônoma em face da independência política brasileira, em 1822. Mas mesmo essas escolas eram elitistas, vinculadas ao Estado ou às ideias naturalistas europeias, e pouco afetas aos problemas da massa da população.

Na República, a busca pela instauração de uma ordem liberal-burguesa propiciou a cultura 
jurídica positivista, ${ }^{4}$ extremamente dogmática. Mesmo porque, segundo Wolkmer (2003, p.778), o liberalismo que as inspirava e que se instalou no Brasil dos séculos XVIII e XIX era, paradoxalmente, de tendência conservadora, "praticado por minorias hegemônicas, antidemocráticas, apegadas às práticas do favor, do clientelismo e da patronagem", restando um liberalismo elitista, antipopular, e que acabou marcado por uma cultura jurídico-institucional formalista, centralizadora, retórica e ornamental.

É por conta desta opção política de certo abstracionismo e neutralidade legal em relação às reais questões sociais no Brasil, adverte Cavalcanti Filho (1972, p.XL-XLIV), que as Constituições de 1824 e 1891, além do Código Criminal do Império (1830), do Código de Processo Criminal (1832), e dos posteriores Código Civil (1916), Código Penal (1940), Código de Processo Civil (1939) e Código de Processo Penal (1941), eram nitidamente inspiradas nos ideais jusnaturalistas ${ }^{5}$

\footnotetext{
${ }^{4}$ O formalismo do positivismo jurídico, explica Wieacker (1967, p.503), era entendido como posicionamento adequado a sociedades rapidamente mutáveis e dominantemente plurais em termos de definições acerca da justiça material; as considerações éticas, sociais, religiosas e econômicas, acaso essas realidades se apresentassem como uma mescla heterogênea e não unânime, não poderiam servir de base para a construção legal ou jurisdicional, sob pena de parcialidade com um ou outro posicionamento. Com o fim das grandes autoridades e a dispersão da ordem social, só o rigor da forma garantiria um mínimo de segurança nas relações humanas de cunho jurídico. Essa autonomia material estava em sintonia com as exigências políticas e econômicas da época liberal, e o seu formalismo também foi importante na consolidação de um Estado de Direito, ou seja, um Estado baseado no respeito à lei. Na realidade jurídica, segundo essa perspectiva positivista, ensina Marques (1998, p.249-53), só seria considerado Direito a legalidade positiva que vigorasse em uma determinada sociedade, e seu vigor significaria que ele tinha força para se impor de modo ativo. Os juristas deveriam se eximir de formular juízos de valor sobre o Direito, devendo olhá-lo como um fato, tal como os cientistas naturais, e as leis seriam entendidas como comandos emanados por uma autoridade legítima; pressupunha-se que o Direito não era contraditório nem lacunoso, e que era devida a cega obediência à lei. A legislação passa a ser considerada a fonte primordial do Direito, em detrimento do costume - como na escola histórica - ou da razão - como na doutrina jusnaturalista; o Direito seria de conteúdo variável no tempo, porém, marcado por um formalismo jurídico no qual o processo de criação do direito positivo e a legitimidade da autoridade que o impunham eram mais importantes à definição do que seria "Direito" do que seu conteúdo material ou sua finalidade. Na estrutura jurídica, o positivismo enfatiza, como princípio fundamental do Direito, o princípio da legalidade.
}

${ }^{5}$ Segundo Wieacker (1967, p.279), "pode designar-se por época do jusnaturalismo os dois séculos (1600-1800) nos quais a antiga filosofia jurídica e social do ocidente ('jusnaturalismo'), na forma que Ihe foi dada pelo primeiro lluminismo, adquiriu uma influência direta sobre a ciência jurídica, a legislação e a jurisprudência da europeus, estes que, muitas vezes, serviam até para fundamentar, cientificamente, a desigualdade social no País (como o foi na questão das raças humanas e da miscigenação); e, do mesmo modo, a mentalidade positivista que passou a exercer forte presença no Brasil das décadas de 30 e 40 do século XX, principalmente na doutrina, sob a regência de autores da Escola de Recife e de São Paulo, era meramente formalista e abstrato-legalista, o que a tornava uma neutralidade cega, e, assim, conservadora, aos graves problemas sociais brasileiros.

Tal abstracionismo firmado consolidou ainda mais a distância entre o direito estatal, eivado pelos interesses das elites econômicas, e as aspirações e necessidades de grupos e classes populares. Além disso, tal distância foi agravada por conta da própria noção de ideário liberal, adotada no Brasil. Assevera Villegas (2002, p.22), neste ponto, que o ideário revolucionário adotado na América Latina foi diferente daquele adotado, por exemplo, na América do Norte. Isto porque, enquanto na América Latina o ideário francês propunha uma noção de cidadania como participação na vontade geral e no ato constituinte da lei, havendo a submissão a ela, após consolidada, o constitucionalismo inglês, adotado na América do Norte, propunha a primordialidade dos direitos individuais, de defesa e dos direitos civis, antes mesmo dos direitos políticos. A lei, assim, na América Latina, representou mais submissão do que potencialidade de direitos efetivos, pois de sua administração e interpretação o cidadão já não mais participava - uma vez instituída, ela não mais poderia ser questionada. E como poucos participavam da elaboração dessa lei, os excluídos dessa participação estavam fadados a suportar, em silêncio, a sua invisibilidade pelo Direito.

Ainda no que se refere a esta consolidação liberal, na formação da legislação civil brasileira, segundo Orlando Gomes (1958, p.34-5), em ten-

maior parte dos povos da Europa”. Em termos históricos, esse período representou uma emancipação da teologia moral e a busca de uma ética social secularizada que pudesse sustentar leis imutáveis e gerais para regular a vida comum dos seres humanos; estas, obtidas com base em um sistema lógico-sistemático - redução do mundo a relações que pudessem ser expressas em números e, assim, tornadas gerais e imutáveis, e das quais seria deduzido todo e qualquer aspecto de sua realidade (visão de um sistema fechado de leis naturais dos fenômenos sociais). 
do permanecido a separação entre a elite letrada e a massa inculta ao tempo de sua elaboração e promulgação, e em sendo esta elite ainda marcada por um teor patriarcalista, tradicional e privatista, vigente no poder dominante dos latifundiários, o Código Civil de 1916 incorporou esse teor quando assumiu os interesses dessa elite letrada e deixou à margem "as condições de vida, os sentimentos e as necessidades das outras partes da população, mantidas em um estado de completa ou meia escravidão". O autor (1966, p.141-6) declara, ainda, em outro texto, que o caráter impessoal do Direito Civil de 1916 acabou por representar um dos sinais mais evidentes da vinculação do direito a uma sociedade de classes, e, em específico, um compromisso para assegurar as condições de posse de todos os meios necessários para a classe dominante continuar a explorar a classe oprimida. Isto porque o direito privado acabou vendo todos os indivíduos em um mesmo plano, sem se indagar das diferenças reais que construíam a forma piramidal da estrutura de poder da sociedade brasileira; além disso, ao focar o estabelecimento de direitos sobre a propriedade, acabou por excluir de seu sistema a imensa massa de homens e mulheres que não eram proprietários; a ênfase principiológica do direito privado sobre a liberdade e autonomia contratual, e ainda, os princípios da sucessão hereditária e do casamento monogâmico perpetuaram, juntos, tal situação de exclusividade da propriedade na dicção dos direitos civis.

A Constituição Brasileira de 1946, influenciada pelo pós-guerra, e no contexto da criação da Declaração dos Direitos Humanos, de 1948, mesmo que de perfil moderado, pois que ela era ainda comprometida com um liberalismo conservador apenas nominalmente democratizante, trouxe algumas conquistas democráticas às classes populares: ela afirmava que todos eram iguais perante a lei (art. $141, \S 1^{\circ}$ ), vetando à União, aos Estados e aos Municípios criar distinções entre brasileiros (art. 31, inciso 7); proibia a propaganda de preconceitos de raça e de cor (art. 141, inciso 5); garantia a liberdade de culto (art. $141, \S 7^{\circ}$ ); declarava os cargos públicos acessíveis a todos os brasileiros (art. 184); além disso, consagrava, no título de suas Garantias Individuais, que ninguém poderia ser perseguido por motivos de raça e de religião, além de proibir a diferença salarial, para um mesmo trabalho, em virtude de idade, sexo, nacionalidade ou estado civil. Ainda, a partir dessa carta magna, a legislação tornou o ensino primário gratuito, e o ginasial gratuito aos que provassem necessidade, nas escolas de educação oficial, a todos os brasileiros, algo que importava muito às classes populares, privadas desse direito até então.

Outro agravante dessa formação excludente das instituições estatais brasileiras se verificava no tratamento dispensado às diferenças raciais e étnicas da época. Em termos de exclusão racial, Schwarcz (1993, p.23-5) atenta para o fato de que também as teorias raciais europeias foram introduzidas no Brasil para justificar as ideias de uma oligarquia que, além de proprietária, deveria ser branca. Aliás, adverte a autora (1993, p.147-85), que por se ter adotado no Brasil abolicionista uma noção de raça e de distinção racial construída pelos homens de ciência das Faculdades de Direito e de Medicina, dos Museus Etnográficos e dos Institutos Históricos Nacionais, noção esta baseada em teses naturalistas de determinismos e evolucionismos raciais de origem europeia, fortemente negatórias à miscigenação e às raças não brancas, a questão da cidadania e da igualdade dos negros, que poderia ter sido oportunizada àquela época, foi abortada, no entendimento de que a igualdade jurídica não poderia superar uma desigualdade natural. Isto espelhou efeitos de negação da cidadania aos homens e mulheres de cor em todas as dimensões de sua vida social.

Na dimensão econômica, evidencia Bertulio (1989, p.40-59), as políticas imigratórias surgidas para prover de mão de obra livre as atividades antes realizadas sob o regime escravocrata, sugeriam uma forte conotação racista ao negro, haja vista não apenas os expressos impedimentos do ingresso no País de mão de obra vinda da África, e também da Ásia (Decreto n 528 de 28/06/1890), com o intuito de "embranquecer" a população, como também pelo fato de ter sido descartada a previsão de ocupar a massa de escravos libertos existentes como trabalhadores livres, o que os deixou na mais absoluta condição de marginalidade econômica. Marginais, também, eram os negros na dimensão política, haja vista que as Constituições de 1824, de 1891, de 1934, de 1937 e de 1946 impediam esses direitos políticos a mendigos e analfabetos, situação 
na qual se enquadrava a maioria dos escravos libertos e seus descendentes até aquele tempo; e ainda, as Posturas Municipais, entre a abolição e o início do século XX, impunham uma condição de marginalidade na dimensão cultural e social aos negros, proibindo seus cantos, danças e bailes, além de pugnarem medidas nitidamente segregatórias ${ }^{6}$ de espaços sociais; a capoeira, por exemplo, foi incluída como crime no art. 402 do Código Penal de 1890, vigente até 1940.

Assim, não é de estranhar, conforme observa Machado Neto (1979), no que se refere às raízes culturais originárias do direito brasileiro, que estas remetiam apenas à cultura lusa, haja vista a consideração de que o direito nativo indígena não compunha um sistema jurídico diferenciado, estando ainda sua regulação social baseada nas formas de folkways e tabus, e de que ao negro, por "sua própria condição servil e a desintegração cultural a que the impelia a imigração forçada a que se via sujeito, não lhe permitiu, também, pudesse competir com o luso na elaboração do direito brasileiro" (MACHADO NETO, 1979, p.310).

A exclusão e desigualdade também perpassaram toda a organização fundiária no País. Segundo Silva (1999, p.32-4), a Lei de Terras de 1850, que substituiu o regime das sesmarias, fez com que o Brasil fosse tomado por uma territorialidade latifundiária que, ao invés de resolver a questão agrária pela ocupação e posse (como o era até 1850), destinando-a às culturas indígenas, negras e colonas que as ocupavam livremente, estipulou que as terras deveriam ser adquiridas pela compra e venda, e mantidas pelo pagamento de impostos e taxas. Esta lei, assim, transformou a propriedade fundiária ou em um monopólio estatal - pois todas as terras não registradas (sesmarias antigas ou registros de compra e venda posteriores) passaram a ser do Estado (terras devolutas e não sujeitas a usucapião) - ou em uma apropriação capitalista, dependente do poder de compra e de manutenção da terra. A proibição da posse como legitimadora da propriedade era também, afirma Martins

\footnotetext{
${ }^{6}$ Bertulio (1989, p.56) exemplifica uma norma constante na Portaria Municipal de São João da Boa Vista (SP), segundo a qual "É proibido ao negociante de molhados consentir em seus negócios, pretos e cativos sem que estejam comprando. O negociante sofrerá multa".
}

(1986, p.42), "dirigida contra os camponeses da época, aqueles que se deslocavam para áreas ainda não concedidas em sesmarias aos fazendeiros e ali abriam suas posses". A solução adotada pela Lei de Terras acabou, do mesmo modo, sendo uma saída para evitar que os estrangeiros que vieram para o Brasil para substituir a mão de obra escrava tomassem posse das terras e, assim, se recusassem a se sujeitar aos preços e condições de trabalho pouco compensadores nas grandes fazendas da época. Deste modo, todos aqueles que não tiveram suas posses legitimadas em sesmarias até 1850 , em sendo todas as terras desocupadas consideradas terras devolutas do Estado, não tinham outra saída para obter subsistência senão trabalhar como mão de obra barata para as grandes fazendas de café e cana da época. A questão fundiária se agravou ainda mais quando foi rebatida na questão política, pois a Constituição Republicana de 1891 transferiu as terras devolutas para os estados federados, estes, marcados, à época, por uma forte oligarquia regional que administrou o direito de concessão dessas terras estatais ao seu bel prazer.

Dessa forma, a desigualdade atingiu todas as instituições estatais e sociais brasileiras, ao exemplo das próprias cartas constitucionais. No que tange à legislação, pensou-se que tal cenário poderia receber modificações com a Constituição de 1934, que introduziu, pela primeira vez, um Constitucionalismo Social no País. Entretanto, o que houve foi uma manobra política para impor um Estado oligárquico-patrimonialista, uma vez que agradava ao trabalhador, dando-lhe alguns direitos com poucas chances de real efetividade. Já as Constituições de 1937 (Estado Novo), 1946 (que restabeleceu a democracia formal representativa e polarizou as principais forças políticas da época: forças conservadoras e grupos liberais reformistas), de 1967 e de 1969 (as duas últimas centralizadoras, arbitrárias e antidemocráticas) representaram um Constitucionalismo, predominantemente, de base não democrática. Foi somente com a Constituição de 1988 que alguns avanços relativos a conquistas democráticas da legalidade e ao acesso à justiça passaram a assumir posição central na pauta de organização dessas instituições estatais, apesar de algumas persistências históricas nelas ainda estarem ativas. 


\section{A formação da vulnerabilidade jurídica no acesso ao judiciário no Brasil}

A formação do judiciário também perpassou esta política centralizadora (da Metrópole e, depois, do Estado) e personalista (afetada pelo poder das elites locais), ficando alheia, praticamente, a todos os problemas dos grupos marginalizados - não proprietários, não brancos, não homens. Aliás, segundo adverte Schwartz (1979, p.73), a burocracia do Império tinha como um dos principais núcleos de seu controle centralizador, justamente, a organização judicial. Esta organização judiciária, continua o autor, do mesmo modo que as demais instituições estatais portuguesas e, depois, brasileiras, apesar de organizada para ser burocrática, impessoal e legalista, acabou eivada dos laços de interesse e de parentesco, ranços do paternalismo da cultura ibérica. Dessa forma, em 1603, houve a criação do Tribunal da Relação da Bahia, com a finalidade de aplicar a lei real, de fortalecer o País contra o ataque de invasores, de defender os índios e de controlar a fraude ao fisco real. Ainda segundo o autor, o tribunal possuía características como a lealdade à Coroa, a imparcialidade local, a competência profissional, a autonomia nas deliberações; ele era composto por letrados profissionais formados na Universidade de Coimbra, coincidindo a sua chegada com a prosperidade econômica açucareira; seus cargos eram distribuídos entre a nobreza tradicional e os letrados, firmando-se a cultura do terceiro nível da burocracia (tabeliães, escrivães e fiscais).

Esse sistema de aplicação da justiça era legitimado por um arcabouço legislativo - as Ordenações Filipinas -, e a Magistratura era tida como a aliada indissociável da Coroa para manutenção deste poder político na colônia. Assim, apesar do rigor no processo seletivo dos juízes, ${ }^{7}$ adverte

\footnotetext{
${ }^{7}$ De acordo com Silveira (2006), o processo de seleção dos magistrados era rigorosamente controlado pelo poder estatal, a fim de garantir certa homogeneidade ideológica para o cumprimento de suas tarefas. Embora muitos dos cargos servissem como moeda de troca em situações específicas, podendo ser comprados com facilidade, o ingresso dos magistrados seguia um procedimento oficial bastante específico, denominado à época de "a Leitura dos Bacharéis", pelo qual o primeiro requisito era ser formado em Direito Civil ou Canônico pela Universidade de Coimbra. Esta exigência perdurou até 1827 , quando houve a criação das duas primeiras faculdades de Direito no Brasil - em Recife e em São Paulo. Outro requisito era a aprovação em concurso público, desenvolvido pelo Desembargo do Paço em Portugal; este incluía a
}

Silveira (2006, p.112-20), ser juiz, no sistema colonial, indicava um mecanismo para satisfazer os interesses pessoais do magistrado, sendo a Universidade e a Magistratura os caminhos para os não nobres ascenderem socialmente e alçarem valorização social e participação no poder político. Esta sedução de poder fez com que se verificassem fortes relações pessoais e sociais, em detrimento das noções de impessoalidade burocrática apregoadas pelo governo central em sua legislação.

Houve algumas mudanças somente com as reformas do Marquês de Pombal, no século $\mathrm{XVIII}$, quando Portugal se reconciliou com as ideias iluministas. Estas reformas limitaram a jurisdição do clero, restringiram os benefícios da nobreza, incrementaram o poder econômico da burguesia e impulsionaram a reformulação do ensino e do modelo universitário. Tal movimento favoreceu a emergência do liberalismo português; também modificou a legislação com a "Lei da Boa Razão" (1769), que definia regras centralizadoras e uniformes para interpretação e aplicação das leis, nos casos de omissão, imprecisão ou lacuna. Devia-se interpretar a legislação de acordo com a lei natural e com as leis das Nações Cristãs iluminadas; mas, adverte Rosenn (1998, p.36-8), sendo o estar de acordo com as "leis da boa razão" definido de modo muito vago, o judiciário supria estas lacunas legais, fomentando a sua "liberdade doutrinária e seu arbítrio".

$\mathrm{Na}$ Constituição da Monarquia, de 1824, pós-independência, continua Rosenn (1998, p.248-9), havia a previsão da independência funcional e de crimes afetos aos atos dos agentes públicos, como o peculato, a prevaricação e o suborno; estava previsto que os futuros juízes deveriam ser bacharéis em Direito, ser maiores de 22 anos e ter reputação ilibada, e que teriam a possibilidade de ascender profissionalmente pela antiguidade no cargo ou pelos serviços prestados à causa pública; no entanto, em suas atividades, ainda não se via a separação entre a coisa pública e a privada (prevalecia um patrimonialismo

\footnotetext{
análise de sua origem social e comunhão pela religião católica, não sendo aceitos, por exemplo, os que tivessem ascendência moura, judaica ou negra, além de se exigir alguns anos de experiência jurídica para ser possível ingressar nos Tribunais de Relação do Reino.
} 
judicial), e a magistratura acabava sendo usada como moeda de troca para privilegiar aliados políticos ou famílias abastadas.

A esperança de se mudar toda esta prática do judiciário veio com a República e com a nova reforma constitucional, na qual se previa maiores garantias necessárias ao correto e autônomo exercício da jurisdição, quais sejam: 1) a descentralização, com o princípio federativo assumido como forma de governo; 2 ) o presidencialismo, caracterizado pela precisa separação dos poderes, pela rotatividade do mandato e pela responsabilidade; 3 ) o equilíbrio efetivo entre os poderes, tendo o judiciário a função de controle das ações das outras esferas políticas; 4) a competência bem delineada entre magistratura estadual e federal. Além disso, havia o procedimento legal específico para ingresso na magistratura, que incluía distinto conhecimento jurídico, experiência nas funções públicas e reputação ilibada; os magistrados possuíam vencimentos próprios e remuneração condigna; ainda, pelo menos na letra da lei, eram previstas medidas para fazer prevalecer a divisão entre a coisa pública e a privada, inclusive com o reforço dos tipos criminais, com a afirmação do império da Lei e, consequentemente, pela imposição mais abstrata da relação mando-obediência no judiciário. A alta elite republicana, no entanto, ainda preenchia os cursos de Direito e os cargos públicos e, ao contrário das promessas da legislação da República, havia realizações a favor de interesses particularistas e setoriais da sociedade.

Como resultado dessas orientações, ora personalistas, ora baseadas na neutralidade técnica na organização do judiciário, surgiram vários problemas operacionais e estruturais, consolidados neste percurso histórico, e que eivavam a jurisdição estatal de ranços da exclusão e da desigualdade, problemas entre os quais Garcia (2002, p.160-1) destaca: a) a falta de legitimidade da justiça, face à sua incapacidade ou ao despreparo histórico para julgar os grandes problemas sociais; b) o fato de o poder jurisdicional não ser totalmente independente, estando muito relacionado com o poder político (o clientelismo político era abundante); c) a configuração da magistratura como uma casta fechada e elitizada; e d) a burocratização e a lentidão dos processos, que dificultam sua eficiência e afastam de seu acesso aqueles que mais precisam de respostas céleres.

Além desses, outros problemas, ainda atuais, também são apontados como limitadores do acesso à justiça no Brasil, entre eles:

1) os entraves econômicos, na inadequação dos sistemas das custas judiciais e extrajudiciais, dos honorários de advogados, de assistentes técnicos e de peritos, das despesas na produção das provas; na inadequação tendo em conta o nível de renda da maior parte da população, apesar da tentativa, com problemas operacionais, de resolver esse entrave com os mecanismos de justiça gratuita. ${ }^{8}$ Nesses entraves econômicos, Fontainha (2009, p.38-42) destaca, também, que as conclusões da pesquisa do Projeto Florença, de Mauro Cappelletti, que afirmavam que os custos enfrentados cresciam, proporcionalmente, à medida que se reduzia o valor da causa, são também verdadeiros no Brasil, causando o que Santos identificou como a "dupla vitimização" das classes populares justiça mais cara para os cidadãos mais débeis, protagonistas das ações de pequeno valor;

2) desequilíbrio entre os atores do litígio, no destaque que Cappelletti $(1988$, p.22) fazia de que os sistemas jurídicos sempre foram mais adaptados aos litigantes organizacionais, afetos ao uso habitual do sistema judiciário no provimento de seus interesses do que aos litigantes individuais, na tutela de suas pequenas causas; e, por fim,

\begin{abstract}
${ }^{8}$ Atualmente, aliás, o acesso à justiça gratuita é um mandamento constitucional, incluso no inciso LXXIV, do art. $5^{\circ}$ de nossa Carta Política de 1988. Conquistas do final da década de 1980 também ampliaram o espectro da justiça gratuita, alterando a Lei $n^{\circ} 1.060$, de 1950, que a rege, para dar o direito à gratuidade da justiça a todos aqueles que, mediante simples afirmação, na própria petição inicial, declararem que não estão em condições de pagar as custas do processo e os honorários de advogado, sem prejuízo do sustento próprio ou de sua família (art. $4^{\circ}$, Lei n 1.060/50). Não há, assim, critérios objetivos de mensuração de pobreza a determinarem a possibilidade ou não de recurso a este direito, ficando cada condição aberta à argumentação da parte beneficiada e à interpretação do juiz, caso a declaração de necessidade da justiça gratuita seja impugnada. Atente-se, assim, para a importância de uma maior consciência de justiça social de nossos magistrados na viabilização desse direito às mais diversas condições de vulnerabilidade econômica de nosso país. Apesar dos avanços, os parcos recursos destinados a atender às necessidades da justiça gratuita, o caráter muito técnico do direito (que dificulta seu conhecimento pelo povo) e a ainda pouca expressiva organização de defensorias públicas estaduais e federais tem prejudicado a operacionalização deste direito de acesso a uma justiça gratuita e de qualidade a ampla gama da população brasileira.
\end{abstract}


3) a versão individualista da figura de Sujeito de Direito, predominante na modernidade, esta que, segundo Souza Jr. (1991, p.138), também tem se apresentado como um problema ao acesso à justiça de grupos populares e vulneráveis, principalmente tendo-se em conta a forma como eles têm se organizado para lutar por seus direitos e participar politicamente na contemporaneidade - a forma de "Novos Movimentos Sociais". $9{ }^{10}$

Da constatação destes problemas adveio, a partir das últimas décadas do século $X X$, a tematização da vulnerabilidade jurídica, traduzida

\footnotetext{
${ }^{9}$ Paoli (1995, p.27) esclarece que a noção de "novos movimentos sociais", no Brasil, serviu para representar os movimentos sociais surgidos (ou reinventados) nas décadas de 70 e 80 - grupos de operários que fizeram greves de maneira independente de seus sindicatos, movimentos populares urbanos (grupos de moradores de bairros desprivilegiados e desatendidos em políticas e ações públicas), movimentos de mulheres, movimento negro, movimentos sociais no campo, movimentos dos povos indígenas - e se referia "ao aparecimento político de atores sociais organizados que não se referenciavam diretamente às estruturas institucionais de poder e representação política - partidos, governos, Estado - nem aos atores 'clássicos' do sistema social - grupos de interesse e classes sociais". Pugnavam por outra esfera de poder, para além do poder político - um poder civil e cidadão, ligado à conquista e ao gozo da cidadania e à busca e consolidação de novos direitos, tendo surgido no momento do fim da ditadura e da restauração do Estado de Direito no País, com a dicção da necessidade de uma reinvenção radical da democracia.
}

\footnotetext{
${ }^{10}$ No sentido dessa negação de acesso à justiça aos movimentos populares, a experiência judiciária do MST (Movimento dos Trabalhadores Sem Terra) é exemplar. O MST, um dos mais organizados movimentos nacionais brasileiros, não é considerado, pelo Estado brasileiro, como um sujeito de direito completo, haja vista ele não se enquadrar nos requisitos formais de uma pessoa jurídica, sendo considerado apenas como uma associação de fato. E esta questão é importante no que tange ao acesso à justiça, ou seja, à legitimidade processual desse movimento. A subjetividade jurídica processual do MST, na jurisprudência nacional, tem sido tratada da seguinte forma. Nas ações em que o Movimento é réu, está suprida a legitimidade de parte pela simples representação deste pelos seus líderes estaduais ou do acampamento, mesmo que a ordem judicial venha a ser cumprida contra todos os do grupo ou mesmo contra algum líder (Apelação Cível $n^{\circ}$ 98.013461-7, de 22/05/2001, do Tribunal de Justiça de Santa Catarina; Apelação Cível $n^{\circ}$ 7.130.729-8, decidida em 24 de agosto de 2007, e Apelação Cível $n^{\circ}$ 7037670-6, decidida em 14/06/2007, ambas, da 24a Câmara de Direito Privado do Tribunal de Justiça do Estado de São Paulo). Isto se dá porque exigir a identificação de todos os membros de um movimento coletivo, como o MST, inviabilizaria qualquer possibilidade de ação pelo proprietário ou possuidor esbulhado ou turbado contra o movimento (Agravo de Instrumento $n^{\circ} 32622$, da Segunda Turma do Tribunal Regional Federal da Quinta Região, de 18/06/2002). Por outro lado, quando na posição de pleiteador de seus direitos e interesses, há importantes restrições ao Movimento, por conta de sua situação de associação de fato, ao direito de acionar a justiça (Agravo de Instrumento $n^{\circ} 70000186833$, da Quarta Câmara Cível do Tribunal de Justiça do Rio Grande do Sul, julgado em 29/12/1999.)
}

nas lutas pelo acesso aos direitos e à justiça, que se refletiu em mudanças importantes na ressignificação do processo judicial, na afirmação de seu compromisso com a justiça social e no questionamento da eficácia da neutralidade do judiciário e da ciência jurídica, em vista das desigualdades reais de poder social e econômico. No impulso do acesso aos direitos e à justiça, também emergiram importantes movimentos, a partir de 1990, sejam internos ao próprio judiciário, como foi o Movimento do Direito Alternativo, sejam externos e autônomos ao Estado, como foram os sistemas de Justiça Comunitária e de Balcão de Direitos. Apesar de ainda apenas mitigarem esses problemas historicamente constituídos no acesso aos direitos e à justiça de grupos que foram lançados à marginalidade, tais movimentos já denotam uma mudança importante no cenário estatal e social brasileiro, mudança esta que deve persistir e se ampliar para que tal vulnerabilidade jurídica histórica possa ser, de vez, superada.

\section{Algumas conquistas no rumo da superação dessas vulnerabilidades jurídicas: avanços no acesso aos direitos e à justiça}

Esta orientação político-ideológico-jurídica que alimentava desigualdades sociais, com destaque, aqui, àquelas que se refletiam na desigualdade na conquista de direitos e no acesso à justiça que os garantiriam, se perpetuou por vários séculos e só passou a assumir a posição de uma questão social de destaque e a produzir efeitos político-jurídicos após o final da ditadura militar, nos primórdios da década de 1980. A partir da Constituição Democrática Brasileira de 1988, a jurisdição passou a visar à realização dos fins de um Estado Social e Democrático de Direito, constituído, assim, pelos princípios da justiça social, do pluralismo, da igualdade e da participação. Portanto, ensina Marinoni (1993, p.21), a questão do acesso aos direitos e à justiça começou a ser tematizada na busca pela superação das desigualdades que impediam o acesso e a efetivação dos direitos:

A questão do acesso à justiça, embora já se fizesse sentir no começo deste século, tanto na Alemanha como na Áustria, somente se fez perceber, de forma definitiva, no pós-guerra. É que com a consagração, a nível constitucional, dos chamados "novos direitos", o direito 
de acesso à justiça passou a ser um direito garantidor de todos os outros. Realmente, como explica Boaventura de Sousa Santos, "uma vez destituídos de mecanismos que fizessem impor o seu respeito, os novos direitos sociais e econômicos passariam a meras declarações políticas, de conteúdo e função mistificadores". Daí a constatação de que a organização da justiça civil e em particular a tramitação processual não podiam ser reduzidas à sua dimensão técnica, socialmente neutra, como era comum serem concebidas pela teoria processualista, devendo se investigar as funções sociais por ela desempenhadas e em particular o modo como as opções técnicas no seu seio veiculavam opções a favor ou contra interesses sociais divergentes ou mesmo antagônicos (interesses de patrões ou operários, de senhorios ou de inquilinos, de rendeiros ou de proprietários fundiários, de consumidores ou de produtores, de homens ou mulheres, de pais ou de filhos, de camponeses ou de citadinos, etc., etc.).

$\mathrm{E}$, ainda, consoante ao entendimento de Marinoni (1993), como o acesso à justiça era o tema ponte a interligar o processo judicial com a justiça social, a neutralidade ideológica do juiz e do jurista, desenvolvida pela dogmática liberal jusnaturalista e, depois, positivista, foi posta em questão. Análises advindas de abordagens sociológicas, neste impulso, começaram a destacar, inclusive, a conotação ideológica do "direito puro e estatal" e a pugnar por uma teoria crítica, não mais separadora, mas, justamente, reveladora das relações de determinação real entre o direito e os demais fatores da estrutura social (a economia, a política, a estrutura de poder, de legitimidade e de cidadania etc.). ${ }^{11} \mathrm{Em}$ termos da América Latina, tal posição crítica foi, inclusive, epistemologicamente desveladora, pondo a nu a condição colonizada e alienada em que se originaram as referências de conhecimento, de política, de teoria social, de direito, em relação aos ditames de países cêntricos europeus e norte-americanos, fazendo, assim, emergir a resistência contra tal colonização em pleitos por uma filosofia, uma teoria social, um direito, um Estado, uma racionalidade, todas compro-

\footnotetext{
${ }^{11}$ Em termos dessa postura crítica de análise jurídica, se encontram, no Brasil, as propostas de Wolkmer (2002); Coelho (1991); Faria (1988); Andrade (2003), entre outros autores.
}

metidas com a emancipação e com a afirmação latino-americana, e atentas às peculiaridades $e$ aos problemas sociais deste continente. ${ }^{12}$

No âmbito do próprio poder jurisdicional, esta tematização do acesso à justiça gerou um importante movimento brasileiro - Movimento do Direito Alternativo. Este que, segundo observa Carvalho (1982, p.88-90), incluía: (1) o Uso Alternativo do Direito, que consistia em utilizar as contradições, ambiguidades e lacunas do direito legislado em uma ótica democratizante e, ainda, em buscar, pela via da interpretação, a abertura de espaços que possibilitassem o avanço das lutas e das conquistas de direitos populares; (2) o Positivismo de Combate, que se empenhava em fazer com que as normas que já haviam sido conquistadas democraticamente como lei se tornassem efetivas de fato, envolvendo a atuação do operador jurídico, mas também as mobilizações populares; e, por fim, o (3) Direito Alternativo em sentido estrito, ou aquela juridicidade paralela, não oficial, insurgente, que existia independentemente do direito estatal.

Este movimento do direito alternativo suscitou um olhar crítico ao poder judiciário, que lhe permitia perceber o enviesamento do Direito e do processo judicial aos interesses dos grupos dominantes e, ao mesmo tempo, desvelar a fragilidade da eficácia e a ausência das leis e dos procedimentos adequados a dar respostas aos amplos e persistentes problemas sociais populares, sendo tal tomada de consciência deveras importante no momento de interpretação e aplicação do Direito aos casos concretos.

Foi a partir deste cenário de redemocratização que algumas conquistas que ampliaram o acesso aos direitos e à justiça se firmaram no Brasil. Entre elas, Wolkmer (2001, p.309) menciona as práticas que emergem como alternati-

\footnotetext{
12 No rol dos autores desse movimento de resistência latino-americano podemos citar várias teorias, movimentos e autores. Entre elas, Wolkmer (2001, p.269.) destaca a Teoria da Dependência (Rui Marini, Theotônio dos Santos, Celso Furtado, Franz Hinkelammert), a Teoria Teológica para a Libertação (Gustavo Gutierrez, Hugo Assmann, Clodovis e Leonardo Boff), as Filosofias da Libertação (Enrique Dussel, Augusto Salazar Bondy, Leopoldo Zea) e Latino-Americana (Alejandro Serrano Caldeira, Raul Fornet-Betancourte), a Pedagogia do Oprimido (Paulo Freire), a Teoria Social baseada em uma Redução Sociológica (Guerreiro Ramos), A Ética da Alteridade (Enrique Dussel) e as proposições de uma filosofia crítica para a política e para o direito (Torre Rangel, David Sanches Rubio, Celso Ludwig).
} 
vas, seja no bojo do próprio sistema oficial e de jurisdicidade - tais como as convenções coletivas de trabalho, as ações propostas por sujeitos coletivos, as instituições da arbitragem, da mediação, da conciliação e dos juizados especiais -, seja de modo marginal e paralelo a ele - como "novas modalidades não institucionais de negociação, mediação, conciliação, juízos arbitrais e júri popular; formas não convencionais, ampliadas e socializadas de juizados especiais de pequenas causas (justiça de mínima quantia); extensão e fragmentação de comitês ou conselhos populares de justiça; criação de tribunais de bairros e de vizinhança; justiça distrital, juizados e juntas itinerantes"; além de novas fontes de produção jurídica por acordos, negociações consensuais, acertos comunitários, entre outros.

Além dessas conquistas no plano da justiça estatal, não se pode deixar de mencionar importantes experiências de viabilização da justiça no plano da sociedade civil e da comunidade, dentre as quais, aqui, se destacam as experiências de Justiça Comunitária e a de Balcão de Direitos.

As experiências de justiça comunitária (que incluem a justiça indígena, campesina, de grupos nativos, de associações de bairro) são um direito alternativo para a solução de conflitos em face da jurisdição estatal, nas quais se destacam aspectos como a organização comunitária, a criação e a aplicação de sistemas normativos próprios e a informalização, ou formalização apenas básica, nos mecanismos de solução dos litígios. Geralmente desenvolvidas por líderes ou autoridades nessas comunidades marginalizadas e em grupos étnicos isolados, tais experiências envolvem, em sua maioria, formas tópicas de jurisprudência, com um forte apelo aos valores comuns (justo local) e aos recursos comunicativos (consensual e conciliatório). Seu modelo tem sido implementado em países como a Colômbia, o Peru, a Bolívia, o Chile e o Brasil, entre outros, sendo uma experiência de juridicidade que tem se multiplicado no cenário latino-americano ao longo dos anos. Estas soluções de justiça comunitária, inclusive, têm sido estudadas pelo Conselho Nacional de Justiça, no Brasil, na busca por sua legitimação e seu reconhecimento pelo Estado.

De forma similar, o projeto "Balcão de Direitos", segundo Ribeiro \& Strozenberg (2001, p.12), procura se integrar à vida das comunida- des, influenciando positivamente a conquista dos direitos individuais e coletivos, por meio de uma leitura do Direito como instrumento político-social de transformação e adequação aos anseios e necessidades da população; ele foi o resultado da solicitação de 25 líderes comunitários junto ao movimento "Viva Rio", em 1996, e a primeira dessas experiências surgiu em 1997, nas comunidades do Chapéu Mangueira e Babilônia, experiências estas que foram apoiadas pelo Ministério da Justiça e pela Fundação Ford. Em 2001, o Rio de Janeiro contava com mais de dez núcleos, envolvendo mais de oitenta pessoas (advogados, estagiários, voluntários, e outros) que trabalhavam nas 17 comunidades que já tinham uma unidade do Balcão. Nessas unidades, a busca é por tentar resolver problemas crônicos das comunidades, como a violência do tráfico de drogas, a ausência de infraestrutura mínima para se viver com dignidade, e a morosidade do sistema judiciário, por meio da mediação para resolução de conflitos; nessa mediação, os diálogos entre os grupos sociais provocam reformulações de discursos e de práticas sociais, rompendo com os preconceitos ainda existentes na cidade do Rio de Janeiro.

Críticas a estas soluções alternativas à justiça estatal, no entanto, também se destacam. Amaya (2007, p.85) admite que o reconhecimento dessas experiências de justiça alternativa pelo Estado tem sido feito de maneira controlada, ou seja, "el Estado regula los alcances de la capacidad de gestión que tiene la comunidad sobre si misma", e, neste controle, a estrutura estatal acaba se apropriando das estruturas comunitárias, maculando-as em suas identidades e autonomia; desta maneira, não é vã, mas, sim, preocupante, adverte o autor, a denúncia de que tais sistemas de justiça comunitária têm se convertido em uma forma de acesso precária aos sistemas de solução de conflitos estatais. Neves (1991, p.17) chega a afirmar que as formas alternativas de solução de conflitos, como as que se fazem, por exemplo, nas favelas cariocas, não passam de formas instáveis e difusas de reação à falta de acesso à justiça oficial, não sendo uma real alternativa à jurisdição oficial.

Apesar disso, a somatória entre as conquistas no âmbito da reorganização das funções jurisdicionais do Estado e o impulso ativo e mediativo dessas experiências mobilizadas na 
própria sociedade civil tem resultado em efeitos muito mais produtivos à superação da vulnerabilidade jurídica no Brasil do que a concentração sobre uma ou outra dessas duas estratégias isoladamente. Estas experiências enunciam também um novo cenário social e institucional. Social, pois denota, segundo Dagnino (1994, p.110), uma nova cidadania, que se revela: 1) no registro de uma sociedade civil emergente, na qual as relações sociais são mediadas pelo reconhecimento e pela representação de interesses, de modo a legitimar as medidas de equidade e as regras de justiça; 2) na pluralização da noção de bem público; 3) na extensão da noção de cidadania para além da relação entre Estado e indivíduo, e do reconhecimento daquele de direitos a este, envolvendo as complexas relações de reconhecimento de direitos que envolvem o Estado, a Sociedade Civil, os Atores sociais e os indivíduos. E Institucional, porque o próprio Estado procura se democratizar em face desse cenário social e reconhecer os processos gerados na sociedade civil. De tal modo que o persistir desse movimento duplo é, a nosso ver, o melhor caminho para a superação da histórica vulnerabilidade jurídica brasileira e para a ampliação e universalização do acesso à justiça.

\section{Conclusões}

Destas discussões, até aqui estabelecidas, pode-se chegar, ainda que preliminarmente, a algumas constatações. Primeiro, é possível destacar que a vulnerabilidade jurídica no Brasil foi iniciada por meio da imunização de alguns princípios modernos, com destaque, dentre eles, para os princípios da igualdade e da dignidade humana, quando da formação do direito legislado e do poder judiciário, imunização esta constituída por ação de ideologias tais como a do personalismo ibérico, a da mescla paradoxal entre o centralismo e a ausência estatal, e pela ação de grupos oligárquicos e conservadores persistentemente no poder. De tal modo que esta organização acabou gerando uma demarcada cisão entre tais elites e a massa da população, em termos de interesses sociais tutelados ou não pela legalidade e pela função judiciária. Nesta cisão, percebeu-se que grupos como os negros, os índios, os não possuidores de terras, os pro- letários foram alijados de participar da formação do direito e da jurisdição nacional, o que resultou não só na carência de direitos para atender às necessidades desses grupos, como também em vácuos em seu acesso à justiça (condição de vulnerabilidade jurídica). Tal cenário, que alimentava desigualdades sociais, mormente aquelas que se refletiam na desigualdade na conquista de direitos e no acesso à justiça que os garantiriam, se perpetuou por vários séculos, passando pelo Império e pela República.

Segundo, os mecanismos de reprodução desta vulnerabilidade foram eficazes, entre outras causas, pelo fato de que, na organização e racionalização das leis e do poder judiciário, estas tiveram por base teorias de neutralidade social e ética, tais como a do jusnaturalismo e a do positivismo jurídico, as quais, somadas a uma visão formal e elitista de democracia, permitiram que esta vulnerabilidade jurídica perdesse (muitas vezes, intencionalmente) visibilidade pública ou nem mesmo fosse tematizada pelas elites políticas.

Mas se pode destacar, como uma terceira constatação, que o atual processo de redemocratização do País e sua característica de estar profundamente envolvido com mobilizações populares desses próprios grupos vulnerabilizados têm consistido em uma superação deste quadro, contribuído para a tematização e a solução dessa vulnerabilidade jurídica historicamente formada, seja no bojo das próprias instituições estatais, seja em experiências criadas e processadas nas comunidades dos grupos vulneráveis, hoje, em processo de reconhecimento público-estatal.

\section{Referências}

AMAYA, E. A. Justicia comunitaria como realidad contemporánea: fundamentos para el análisis de las políticas públicas. In. TORRE RANGEL, J. A. de la. (Org.). Pluralismo Jurídico. Teoria y Experiências. San Luis Potosi, México: Departamento de Publicaciones de la Faculdad de Derecho, 2007, p.75-106.

Hacia un modelo de justicia desde la comunidade. Justicia y desarrollo. Debates. Paz e democracia: el aporte de la justicia comunitária. ISSN 0123-3726. Bogotá. Ano 2, nº 10, p.54-64, diciembre 1999. 
ANDRADE, V. R. P. de. Sistema penal máximo $x$ cidadania mínima: códigos da violência na era da globalização. Porto Alegre: Livraria do Advogado, 2003.

ARRUDA Jr. (Org.). Lições de direito alternativo. São Paulo: Acadêmica, 1991.

BERTULIO, D. L. L. Direito e relações raciais: uma introdução crítica ao racismo. (Dissertação). Florianópolis: Universidade Federal de Santa Catarina, 1989.

CAPPELLETTI, M. Acesso à justiça. Tradução de Ellen Gracie NorthFleet. Porto Alegre: Fabris, 1988.

CARVALHO, A. B. Magistratura e direito alternativo. São Paulo: Acadêmica, 1992.

CAVALCANTI FILHO, T. Introdução. In: REALE, M. Fundamentos do Direito. $2^{\mathrm{a}}$ ed. São Paulo: Revista dos Tribunais, 1972.

COELHO, L. F. Teoria crítica do Direito. $2^{\mathrm{a}}$ ed. Porto Alegre: Sérgio Antonio Fabris, Editor, 1991.

CESAR, A. Acesso à justiça e cidadania. Cuiabá: EdUFMT, 2002.

DAGNINO, E. Os movimentos sociais e a emergência de uma nova noção de cidadania. In: . (Org.).

Os anos 90: política e sociedade no Brasil. São Paulo: Brasiliense, 1994.

FAORO, R. Os donos do poder: formação do patronato político brasileiro. $3^{\mathrm{a}}$ ed. São Paulo: Globo, 2001.

FARIA, J. E. A crise do direito em uma sociedade em mudança. Brasília: UnB, 1988.

FONTAINHA, F. de C. Acesso à justiça: da contribuição de Mauro Cappelletti à realidade brasileira. Rio de Janeiro: Lumen Juris, 2009.

GARCIA, M. P. V. Justicia embera, identidad y cambio cultural (reflexiones en torno a una experiencia). EI otro derecho. Pluralismo jurídico y alternatividad judicial, $n^{\circ}$ 26-27, abril de 2002.

GARCIA, R. Aproximación a los mecanismos alternativos de resolución de conflictos en América Latina. El otro derecho. Pluralismo jurídico y alternatividad judicial, $\mathrm{n}^{\circ} 26-27$, abril de 2002, p.160-1.

GOMES, O. Conteúdo de classe no Direito Civil. In: MACHADO NETO, A. L. (Org.). O Direito e a vida social. São Paulo: Companhia Editora Nacional, 1966.
. Raízes históricas e sociológicas do Código Civil Brasileiro. Salvador: Livraria Progresso, 1958.

LYRA FILHO, R. O que é direito. São Paulo: Brasiliense, 1999. (Coleção Primeiros Passos.)

MACHADO NETO, A. L. Sociologia jurídica. $4^{\text {a }}$ ed. São Paulo: Saraiva, 1979.

MARINONI, L. G. Novas linhas do processo civil: o acesso à justiça e os institutos fundamentais do direito processual. São Paulo: Revista dos Tribunais, 1993.

MARQUES, M. R. Grandes linhas de evolução do pensamento e da filosofia jurídicos. In: CUNHA, P. F. Instituições de Direito. Filosofia e metodologia do direito. Coimbra: Livraria Almedina, 1998.

MARTINS, J. S. Os camponeses e a política no Brasil. As lutas sociais no campo e seu lugar no processo político. $3^{\mathrm{a}}$ ed. Petrópolis: Vozes, 1986.

MONREAL, E. N. O Direito como obstáculo à transformação social. Porto Alegre: Sérgio Antônio Fabris Editor, 1988.

NEVES, M. Do pluralismo jurídico à miscelânea social: o problema da falta de identidade da(s) Esfera(s) de juridicidade na modernidade periférica e suas implicações na América Latina. Direito em Debate. Universidade de ljuí, v.1, nº 1. 1991, p.7-27, p.17.

PAOLI, M. C. Movimentos sociais no Brasil: em busca de um estatuto político. In: HELLMANN, M. Movimentos sociais e democracia no Brasil. "Sem a gente não tem jeito". São Paulo: Marco Zero - Ildesfes Labor, 1995.

PAULILO, M. I. S. Terra à vista ... e ao longe. Florianópolis: Editora da UFSC, 1996.

RIBEIRO, P. J.; STROZENBERG, P. Balcão de direitos: resolução de conflitos em favelas do Rio de Janeiro. Rio de Janeiro: Mauad, 2001.

ROSENN, K. S. O jeito na cultura jurídica brasileira. Rio de Janeiro: Renovar, 1998.

SCHERER-WARREN, I. Redes de movimentos sociais. São Paulo: Loyola, 1993.

SCHWARCZ, L. M. O espetáculo das raças: cientistas, instituições e questão racial no Brasil 1870-1930. São Paulo: Companhia das Letras, 1993.

SCHWARTZ, S. B. Burocracia e sociedade no Brasil colonial. São Paulo: Perspectiva, 1979.

SILVA, J. A. Ação popular constitucional: doutrina e processo. São Paulo: Revista dos Tribunais, 2007. 
SILVA, M. A. de M. Errantes do fim do século. São Paulo: Editora da Unesp, 1999.

SILVEIRA, D. B. Patrimonialismo e burocracia: uma análise sobre o poder judiciário na formação do Estado brasileiro. (Dissertação.) Brasília: Universidade de Brasília, 2006.

SLEMIAN, A.; PIMENTA, J. P. G. O "nascimento político do Brasil": as origens do Estado e da nação (1808-1852). Rio de Janeiro: DPCA, 2003.

SOUZA, J. A construção social da subcidadania: para uma sociologia política da modernidade periférica. Rio de Janeiro: luperj, 2006.

TELLES, V. S. Sociedade civil e a construção de espaços públicos. In: DAGNINO, Evelina (Org.). Os anos 90: política e sociedade no Brasil. São Paulo: Brasiliense, 1994.

VILLEGAS, M. G. Notas preliminares para la caracterización del derecho em América Latina. EI otro derecho. Pluralismo jurídico y alternatividad judicial. n²6-27, p.13-48, abril de 2002.

WIEACKER, F. História do Direito Privado Moderno. $2^{\mathrm{a}}$ ed. Lisboa: Fundação Calouste Gulbenkian, 1967.

WOLKMER, A. C. Pluralismo jurídico: fundamentos de uma nova cultura no Direito. $3^{a}$ ed. São Paulo: Alfa-Ômega, 2001.

História do Direito no Brasil. $3^{\mathrm{a}}$ ed. Rio de Janeiro: Forense, 2003.

Introdução ao pensamento jurídico crítico.

4ª ed. São Paulo: Saraiva, 2002. 